\title{
Oomycete Species Associated with Soybean Seedlings in North America-Part I: Identification and Pathogenicity Characterization
}

\begin{abstract}
J. Alejandro Rojas, Janette L. Jacobs, Stephanie Napieralski, Behirda Karaj, Carl A. Bradley, Thomas Chase, Paul D. Esker, Loren J. Giesler, Doug J. Jardine, Dean K. Malvick, Samuel G. Markell, Berlin D. Nelson, Alison E. Robertson, John C. Rupe, Damon L. Smith, Laura E. Sweets, Albert U. Tenuta, Kiersten A. Wise, and Martin I. Chilvers

First, second, third, fourth, and nineteenth authors: Department of Plant, Soil and Microbial Sciences, Michigan State University, East Lansing 48824; first and nineteenth authors: Program in Ecology, Evolutionary Biology and Behavior, Michigan State University; fifth author: Department of Crop Sciences, University of Illinois, Urbana 61801; sixth author: Department of Plant Science, South Dakota State University, Brookings 57007; seventh and fifteenth authors: Department of Plant Pathology, University of Wisconsin, Madison 53706; eighth author: Department of Plant Pathology, University of Nebraska, Lincoln 68583; ninth author: Department of Plant Pathology, Kansas State University, Manhattan 66506; tenth author: Department of Plant Pathology, University of Minnesota, St. Paul 55108; eleventh and twelfth authors: Department of Plant Pathology, North Dakota State University, Fargo 58105; thirteenth author: Department of Plant Pathology and Microbiology, Iowa State University, Ames 50011; fourteenth author: Department of Plant Pathology, University of Arkansas, Fayetteville 72701; sixteeenth author: Division of Plant Sciences, University of Missouri, Columbia 65211; seventeenth author: Ontario Ministry of Agriculture, Food \& Rural Affairs, Ridgetown, ON NOP2C0, Canada; and eighteenth author: Department of Botany and Plant Pathology, Purdue University, West Lafayette, IN 47907.
\end{abstract}

Current address for C. A. Bradley: Department of Plant Pathology, University of Kentucky, Princeton 42445.

Current address for P. D. Esker: School of Agronomy, University of Costa Rica, San Jose.

Accepted for publication 25 October 2016.

\begin{abstract}
Oomycete pathogens are commonly associated with soybean root rot and have been estimated to reduce soybean yields in the United States by 1.5 million tons on an annual basis. Limited information exists regarding the frequency and diversity of oomycete species across the major soybean-producing regions in North America. A survey was conducted across 11 major soybean-producing states in the United States and the province of Ontario, Canada. In 2011, 2,378 oomycete cultures were isolated from soybean seedling roots on a semiselective medium (CMAPARPB) and were identified by sequencing of the internal transcribed spacer region of rDNA. Sequence results distinguished a total of 51 Pythium spp., three Phytophthora spp., three Phytopythium spp., and one Aphanomyces sp. in 2011, with Pythium sylvaticum (16\%) and P. oopapillum (13\%) being the most prevalent. In 2012, the survey was repeated, but, due to drought conditions across the sampling area, fewer total isolates $(n=1,038)$ were collected. Additionally, in 2012, a second

semiselective medium (V8-RPBH) was included, which increased the Phytophthora spp. isolated from 0.7 to $7 \%$ of the total isolates. In 2012, 54 Pythium spp., seven Phytophthora spp., six Phytopythium spp., and one Pythiogeton sp. were recovered, with P. sylvaticum (14\%) and $P$. heterothallicum $(12 \%)$ being recovered most frequently. Pathogenicity and virulence were evaluated with representative isolates of each of the 84 species on soybean cv. Sloan. A seed-rot assay identified 13 and 11 pathogenic species, respectively, at 13 and $20^{\circ} \mathrm{C}$. A seedling-root assay conducted at $20^{\circ} \mathrm{C}$ identified 43 species as pathogenic, having a significantly detrimental effect on the seedling roots as compared with the noninoculated control. A total of 15 species were pathogenic in both the seed and seedling assays. This study provides a comprehensive characterization of oomycete species present in soybean seedling roots in the major production areas in the United States and Ontario, Canada and provides a basis for disease management and breeding programs.
\end{abstract}

Soybean (Glycine max [L.] Merr.) is second only to corn (Zea mays) in the United States in importance for feed and industrial uses. Poor crop establishment and plant stand due to seed and seedling diseases greatly reduces the soybean crop yield potential in many areas. In 2009, soybean yield loss as a result of seedling diseases in the United States was estimated to be 1.51 million tons (Koenning and Wrather 2010). Many factors may influence plant stand and root health, such as seed quality, edaphic, and environmental conditions (e.g., soil type, soil moisture, precipitation, and temperature), soil microorganisms, and especially diseases (Broders et al. 2009). Soilborne seed and root diseases are attributed to many pathogens, including Fusarium and Rhizoctonia

Corresponding author: M. I. Chilvers; E-mail address: chilvers@msu.edu

*The $\boldsymbol{e}$-Xtra logo stands for "electronic extra" and indicates that six supplementary figures, three supplementary tables, and one supplementary file are published online.

(c) 2017 The American Phytopathological Society species from the kingdom Fungi and the oomycetes Pythium and Phytophthora from the kingdom Stramenopila (Anderson 1987; Kaufmann and Gerdemann 1958; Rizvi and Yang 1996). In the United States, there has been an increase in soybean yield loss caused by the oomycetes Phytophthora and Pythium (Koenning and Wrather 2010; Wrather and Koenning 2009). This increased incidence of oomycete-related diseases could be due to lack of material resistant to Pythium spp., pathotypes of Phytophthora sojae able to overcome existing Rps resistance genes, changes in precipitation patterns, and cultural practices used by growers, such as earlier planting dates and greater rainfall in spring and early summer, in conjunction with minimum tillage practices (Dorrance et al. 2016; Melillo et al. 2014).

Conducive environmental conditions for root and seed rot are generally considered to be moist soils, low temperatures that result in delayed seed germination, and plant stress (Leopold and Musgrave 1979) and free moisture, ideal for oospore germination, zoospore production, and subsequent plant infection (Broders et al. 2007; Martin and Loper 1999). Seedling and root-rot diseases can impact yield through plant stand loss, but they are also capable of 
causing sublethal infections that impact plant health and yield (Kirkpatrick et al. 2006; Schlub and Lockwood 1981). Phytophthora and Pythium spp. are two of the most widely recognized genera of seedling pathogens of soybean. Although Phytophthora sojae is a common root and stem rot pathogen of soybean, it can also cause damping off of seedlings (Tyler 2007). Several Pythium spp. are reported to have a major impact at the seed and seedling stage in soybean and other field crops (Broders et al. 2007; ZitnickAnderson and Nelson 2015). According to a host-fungal database, 16 Pythium spp. have been confirmed as plant pathogens having an association with soybean (Farr and Rossman 2013). However, studies of oomycete species associated with soybean root rot are often limited or restricted to individual states (Broders et al. 2009; Jiang et al. 2012; Rizvi and Yang 1996; Zitnick-Anderson and Nelson 2015). Nonetheless, information provided by these studies has been extremely valuable in identifying common causal agents of root rot in soybean, including Pythium ultimum, $P$. irregulare, and P. sylvaticum.

In the United States, soybean production acreage is concentrated in the Midwest and within limited regions of the South. In Canada, Ontario is the major soybean-producing province, followed by Manitoba and Quebec. Thus, soybean production occurs across a large area of North America. These areas encompass a vast diversity of environmental and edaphic conditions that could affect oomycete species composition. In addition, cultural practices, such as crop rotation and soybean cultivar selection, can potentially affect the oomycete communities present in a given area. Broders et al. (2009) conducted an extensive Pythium community survey in Ohio and reported an association of $\mathrm{pH}$, calcium, and field capacity with five Pythium communities designated, based on species composition. Zitnick-Anderson et al. (2014) studied the effect of soil properties on Pythium communities from soybean roots in North Dakota, finding that levels of zinc were associated with increasing abundance of $P$. ultimum and cation exchange capacity correlated with specific species, such as $P$. kashmirense, $P$. heterothallicum, and $P$. irregulare, increasing their frequency.

To gain a better understanding of the diversity of oomycete species causing soybean seedling diseases in the United States and Ontario, Canada, an extensive survey was conducted in 2011 and 2012. The survey included 11 of the 31 reported soybean-producing states in the United States and in Ontario. These states constitute the soybean belt and they produce $77 \%$ of the total soybeans produced in the United States (United States Department of Agriculture (USDA) National Agricultural Statistics Service). The objectives of this study were to determine the diversity and frequency of oomycete species associated with diseased soybean seedlings across the major soybean production area of North America and then, using a classic culture-based survey, characterize these species to determine the key pathogenic oomycete species responsible for seed rot and for root rot. The knowledge gained will inform future efforts toward oomycete management through improved diagnostics, screening of soybean breeding material, and improved chemical management approaches.

\section{MATERIALS AND METHODS}

Sample collection and isolation. In 2011 and 2012, a survey was conducted across 11 states, covering the primary United States soybean production area, and Ontario, Canada (Fig. 1; Supplementary Table S1). A total of 64 and 61 fields, respectively, were sampled in 2011 and 2012. Approximately six fields were sampled per year in each participating state and those fields were selected based on field history of seedling diseases and plant stand issues. Collaborators followed a standard sampling procedure that specified collection of 50 symptomatic soybean seedlings from a W-shaped transect across each field. Due to crop rotation practices, diseased soybean fields sampled in 2011 were different from the fields sampled in 2012. Seedling samples from the field were transported to the laboratory in coolers and were refrigerated; all plant samples were processed within $24 \mathrm{~h}$ postcollection. Seedlings were prepared for isolation by washing them under running tap water for $30 \mathrm{~min}$, until all visible soil was removed. Seedlings were patted dry with sterile paper towels to remove excess water and $1-\mathrm{cm}$ root sections of symptomatic tissue were removed, using a sterile scalpel. Sections from all 50 plants per field were placed onto a semiselective medium, corn meal agar (CMA-PARPB) amended with pentachloronitrobenzene (PCNB) (50 mg/liter), ampicillin (250 mg/liter), rifampicin (10 mg/liter), pimaricin ( $5 \mathrm{mg} /$ liter $)$, and benomyl (10 mg/liter) (Jeffers 1986). For 2012, an additional semiselective medium was included to increase the recovery of Phytophthora spp., i.e., 4\% V8 medium (V8-RPBH) that contained calcium carbonate $\left(\mathrm{CaCO}_{3}, 0.6 \mathrm{~g} /\right.$ liter $)$, sucrose $(1 \mathrm{~g} /$ liter $)$, yeast extract $(0.2 \mathrm{~g} /$ liter $)$ amended with rifampicin ( $10 \mathrm{mg} / \mathrm{liter}), \mathrm{PCNB}$ (20 mg/liter), benomyl (10 mg/liter), and hymexazol (20 mg/liter) (Dorrance et al. 2008). Half of the 50 seedlings per field were plated on the CMA-PARPB medium and half were plated onto the V8-RPBH medium. Culture plates were incubated for 7 days at room temperature $\left(20^{\circ} \mathrm{C}\right)$ and were checked daily for hyphal growth and morphology consistent with oomycetes. If oomycete mycelial growth was observed, cultures were transferred to fresh CMA-PARPB or V8-RPBH medium by hyphal tipping. Pure isolates were shipped to Michigan State University for identification and characterization.

Isolate storage and DNA extraction. Isolates shipped to Michigan State University were transferred to CMA-PARPB medium and 5-mm plugs were taken from fresh cultures and were transferred to potato carrot agar slants and hemp seed vials for longterm storage (Erwin and Ribeiro 1996; van der Plaats-Niterink 1981). Three to five 5-mm plugs from fresh cultures were transferred into $50 \mathrm{ml}$ of a $10 \% \mathrm{~V} 8$ broth amended with ampicillin (100 mg/liter) in 125-ml Erlenmeyer flasks and were incubated for 7 to 10 days at room temperature, without agitation. Mycelia were harvested from broth cultures, were lyophilized overnight, and were ground for DNA extraction. For DNA extraction, $100 \mathrm{mg}$ of ground mycelia were resuspended in $800 \mu$ l cetyltrimethylammonium bromide lysis buffer (AutoGen AG00121, AutoGen Inc.) and were incubated for $1 \mathrm{~h}$ at $65^{\circ} \mathrm{C}$. A phenol-chloroform automated DNA extraction was performed using the AutoGen 850 system (AutoGen Inc.). DNA was resuspended in $200 \mu \mathrm{l}$ Tris-EDTA (TE) buffer, was incubated on an orbital shaker for $1 \mathrm{~h}$, was then transferred to 1.5 -ml tubes, and was stored at $-20^{\circ} \mathrm{C}$.

Identification of isolates. Isolates were identified using internal transcribed spacers (ITS) 1 and 2 of rDNA, by amplification with primers ITS6 and ITS4 (Cooke et al. 2000). The polymerase chain reaction (PCR) amplifications consisted of a final concentration of $1 \times$ DreamTaq buffer, $2 \mathrm{mM} \mathrm{MgCl}_{2}, 0.2 \mathrm{mM} \mathrm{dNTPs}$, $0.2 \mu \mathrm{M}$ ITS6, and $0.2 \mu \mathrm{M}$ ITS4, $4 \mu \mathrm{g}$ of bovine serum albumin per milliliter, $1 \mathrm{U}$ of DreamTaq polymerase (Thermo Scientific), and $1 \mu \mathrm{l}$ of DNA. The amplification program consisted of $95^{\circ} \mathrm{C}$ for $2 \mathrm{~min} ; 35$ cycles of $95^{\circ} \mathrm{C}$ for $1 \mathrm{~min}, 55^{\circ} \mathrm{C}$ for $1 \mathrm{~min}$, and $72^{\circ} \mathrm{C}$ for $1 \mathrm{~min}$; and a final extension at $72^{\circ} \mathrm{C}$ for $10 \mathrm{~min}$. Amplicons were purified by adding $5 \mu \mathrm{l}$ of a mixture of $3 \mathrm{U}$ of exonuclease I and $0.5 \mathrm{U}$ of FastAP thermosensitive alkaline phosphatase (Thermo Scientific). Samples were incubated for $45 \mathrm{~min}$ at $37^{\circ} \mathrm{C}$, and enzymes were inactivated by incubation at $85^{\circ} \mathrm{C}$ for $10 \mathrm{~min}$. Amplicons were Sangersequenced in both directions, and consensus sequences were queried against a curated database of oomycete ITS sequences (Robideau et al. 2011) by using the BLASTn search algorithm for identification (Altschul et al. 1990). Samples with a bitscore higher than 1,000 and identity higher than $97 \%$ were assigned to a taxonomic designation based on the BLAST output. Sequences were deposited in GenBank under accession codes KU208091 to KU211502.

Seed pathogenicity assay. When available, three isolates of each identified species, which were arbitrarily selected, were evaluated for pathogenicity and virulence on soybean seeds. For a limited number of species, isolates obtained from corn were 
substituted, in order to screen three isolates per species for pathogenicity as indicated in Supplementary File 1. A total of 207 isolates representing 84 oomycete species were characterized. A petri-dish seed-pathogenicity assay was conducted as reported by Broders et al. (2007) with the following modifications: isolates were grown on CMA for 4 to 7 days, and a 5-mm plug was transferred from this CMA active culture to the center of a $1.5 \%$ water agar plate and was incubated for 2 days. Seeds of the soybean cultivar Sloan were surface-disinfested with a $0.36 \%$ sodium hypochlorite solution for $10 \mathrm{~min}$, were rinsed with sterile, distilled water three times, and were allowed to air dry in a laminar flow hood for $15 \mathrm{~min}$. Ten seeds were placed at the growing edge of the colony. Plates were incubated in the dark for 7 days at 13 or $20^{\circ} \mathrm{C}$. These temperatures were based on the average soil temperature at planting in northern and southern United States climates (Rojas et al. 2017). Each isolate was evaluated on three replicate plates at each temperature and the experiment was conducted three times per temperature.
Seeds were assigned a disease severity value using the following rating scale: $0=$ germinated healthy seed, $1=$ delayed development with minimal or no discoloration, 2 = germination with isolated lesions, 3 = germination with coalesced lesions, and $4=$ no germination and seed colonized. A disease severity index (DSI) was calculated using the formula:

$$
\text { DSI }=\frac{\sum(\text { severity rating } \times \text { seeds per rating })}{(\text { total seeds } \times \text { highest severity rating })} \times 100
$$

Due to the large number of isolates and replicates, the species were divided into seven sets, with each set containing a control without pathogen. A linear mixed model was used to evaluate DSI as a response variable and species as a fixed effect and nesting isolates within species and experiment as a random effect. Dunnett's contrast was applied to determine species that were significantly different from the control. Temperatures were analyzed

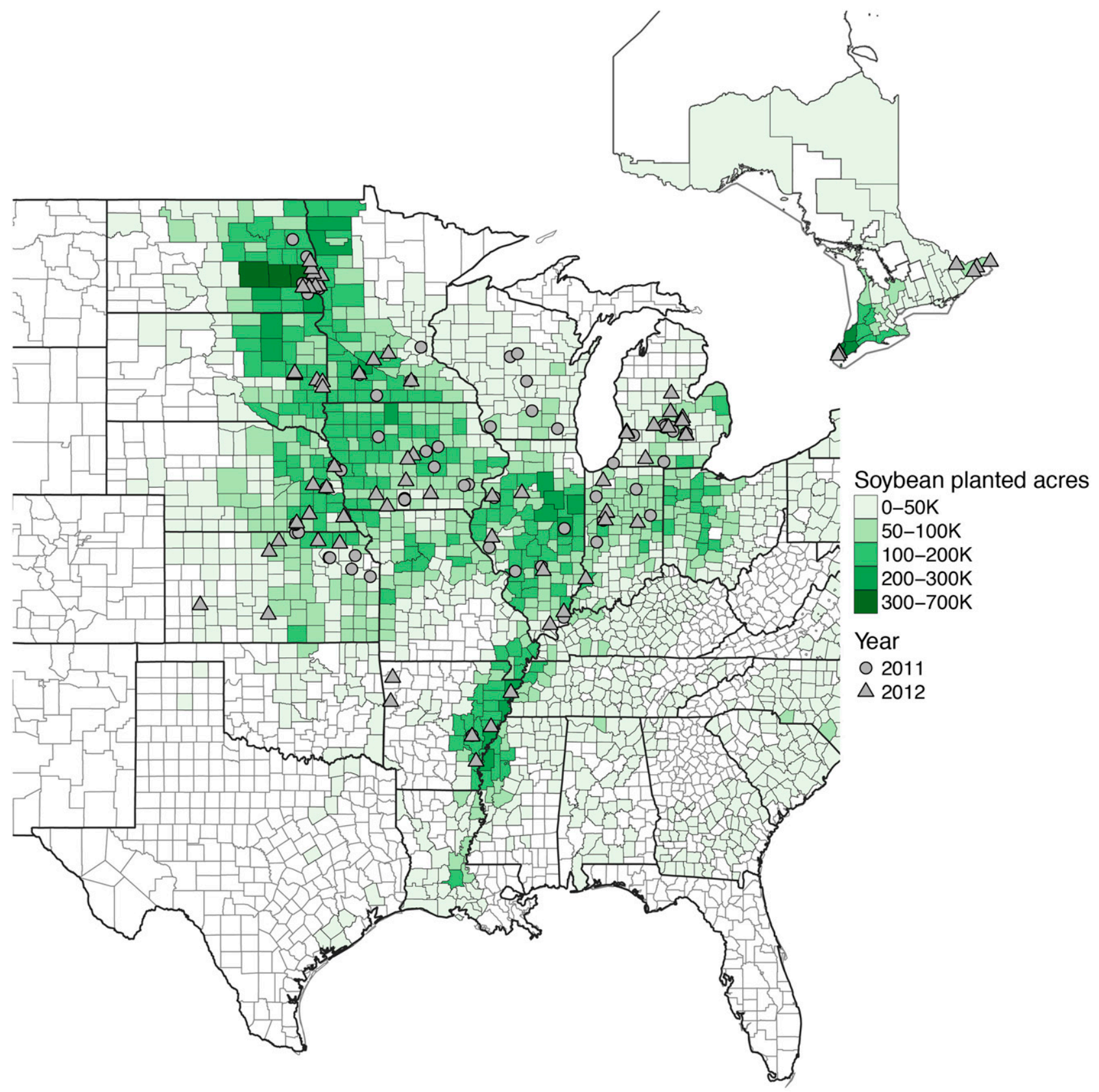

Fig. 1. Map of sampled soybean fields in 2011 and 2012 and of intensity of planted soybean acres demonstrated by color intensity at the county/parish/province level. 
independently. In addition, hierarchical clustering was performed to separate species into a cluster, using DSI at 13 and $20^{\circ} \mathrm{C}$. Statistical analyses were conducted in $\mathrm{R}$ version 3.2 ( $\mathrm{R}$ core team 2015, Vienna, Austria), using packages 'lme4' and 'lsmeans,' and graphs were generated with the package 'ggplot2.'

Seedling root-rot assay. The same isolates used for the seed pathogenicity assay were also evaluated in a seedling root-rot assay. Inoculum was prepared by placing $25 \mathrm{~g}$ of long-grain rice and $12 \mathrm{ml}$ of distilled water in 125-ml flasks, and then, autoclaving for $25 \mathrm{~min}$ and cooling overnight (Holmes and Benson 1994). The rice grains were mixed using a sterile technique, were autoclaved for another $30 \mathrm{~min}$, and were cooled overnight. Five 5-mm plugs from 4- to 7day-old cultures of each isolate were transferred into the rice flasks and were incubated in the dark at room temperature $\left(20\right.$ to $\left.22^{\circ} \mathrm{C}\right)$ for 10 to 14 days. The rice inoculum was mixed regularly to ensure full colonization of rice grains and to loosen and separate grains. Seedling assays were performed in $355-\mathrm{ml}$ capacity paper cups (Solo cups) with four $0.5-\mathrm{cm}$ drainage holes in the bottom. Cups were layered from bottom to top with $50 \mathrm{ml}$ of coarse vermiculite, $150 \mathrm{ml}$ of fine vermiculite, $7 \mathrm{~g}$ of colonized rice, $100 \mathrm{ml}$ of fine vermiculite, 6 soybean cv. Sloan seeds, and $100 \mathrm{ml}$ of coarse vermiculite. The vermiculite substrate was initially moistened to water-holding capacity, and thereafter, plants were watered every other day with de-ionized water. Cups were maintained in a growth chamber (BioChambers) with a light regime of $14 \mathrm{~h}$ of light $\left(250 \mu \mathrm{E} \mathrm{m}^{-2} \cdot \mathrm{s}^{-1}\right)$ and $10 \mathrm{~h}$ of dark, at $98 \%$ humidity and $20^{\circ} \mathrm{C}$ for 14 days. Due to the large number of isolates, the isolates were grouped by species and were randomly assigned into seven sets that were used as a block. Every isolate had three cup replicates per experiment, and each experiment was conducted three times for every set. Two controls were included within every experiment, a control with noninoculated autoclaved rice and a non-rice control to account for any effects of the rice on the seedlings. At the completion of the experiment, plant roots were washed with tap water to remove debris for evaluation. Five washed plants were scanned to determine root area and root length and were placed in a drying oven at $50^{\circ} \mathrm{C}$ for 48 to $72 \mathrm{~h}$, to establish dry weight of roots and shoots. Reisolations were made as described below.

Koch's postulates and single-strand conformation polymorphism (SSCP) confirmation. To fulfill Koch's postulates, in each seedling root-rot experiment, a single plant was arbitrarily selected from one of the three replicates for reisolation of the pathogen. Plants were washed with tap water to remove vermiculite and isolations were performed as described above. Plates were incubated at room temperature for 7 days and were checked daily for the presence of mycelia with growth characteristic of oomycetes. When hyphal growth was observed, transfers were made onto CMA-PARPB medium. Incubation time was extended 7 days for plates without any growth, after the initial incubation period.

The identity of the isolates was confirmed by SSCP (Kong et al. $2004,2005)$. In order to have a positive confirmation, colony PCR was conducted on the isolate inoculated and the isolate recovered from infected root tissue, using primers ITS6 and ITS7 (Kong et al. 2004). Briefly, a small fragment of mycelia was taken from the plate, was placed into $100 \mu \mathrm{l}$ of sterile distilled water and boiled for $5 \mathrm{~min}$ in a heat block at $95^{\circ} \mathrm{C}$, and $1 \mu \mathrm{l}$ of this boil prep was used for PCR. Amplification was completed as described previously, using primers ITS6 and ITS7. The PCR products were used for the SSCP analysis, following methods described by Kong et al. (2004). To ease scoring of gels, denatured PCR products from each original and recovered isolate were run side by side in the polyacrylamide gel. Isolation and SSCP confirmation were conducted for each experiment, thus each isolate had three reisolation attempts.

Root area and root length image analysis. Images of roots from the seedling root-rot assay were obtained with a flatbed scanner (Epson Perfection 4870 Photo Pro; Epson America, Inc.) at a resolution of $300 \mathrm{dpi}$ and saved as JPEG files. Every image included a photographic reference scale to calibrate measurements from pixels to centimeters. All images were analyzed with Assess 2.0 (American Phytopathological Society), using HSI color space (hue values between 0 and 121) to limit the selection to just root tissue, for determination of root area and length, using a calibrated scale.

Data analysis for root measurements. A multivariate analysis of variance (MANOVA) was performed to evaluate seedling variables measured, i.e., root dry weight, shoot dry weight, shoot/ root weight ratio, root area, and root length. Prior to analysis, the variables were $\log 10$ transformed to improve normality and scaled and centered to aid analysis. An initial exploration of all the response variables was conducted, using principal component analysis (PCA), and the contribution of each variable was examined. Based on contribution, a MANOVA test was utilized to examine differences among the 84 oomycete species characterized, using root dry weight, root area, and root length as response variables. Species was treated as a fixed effect, while isolates and experiment were treated as random effects. To verify significance, univariate analyses were conducted for each of the correspondent response variables using the same model. Dunnett's test was used to determine those species significantly different from the non-rice control. Data were analyzed using R version 3.2 (R core team 2015) with packages 'FactoMineR', 'nlme', 'MASS' and 'lsmeans', and graphs were generated with the package 'ggplot2'. All data and R scripts used in the analyses shown here are deposited on github (https://github.com/Chilverslab/Rojas_Survey_Phytopath_2016) (Rojas et al. 2016).

\section{RESULTS}

Sample collection. A total of 3,418 oomycete isolates were collected during the two-year study, 2,380 isolates in 2011 and 1,038 isolates in 2012. A total of 84 oomycete species were identified (Fig. 2), using the ITS region of the rDNA. The genus Pythium was the most dominant across the samples, followed by Phytophthora, Phytopythium, and Aphanomyces spp. In 2011, the 12 most abundant species recovered, which included more than $78 \%$ of total isolates, were P. sylvaticum (16.3\%), P. oopapillum (13.3\%), P. irregulare (10.1\%), P. heterothallicum (7.9\%), P. aff. torulosum $(4.7 \%)$, P. spinosum $(4.6 \%)$, P. ultimum var. ultimum (4.5\%), P. aff. dissotocum (4.4\%), P. lutarium (4.1\%), P. paroecandrum (2.9\%), P. attrantheridium (2.8\%), and P. ultimum (2.8\%) (Fig. 2). In 2012 , there was a shift in the frequency of species isolated; however, there were similarities between the two years. Seven of the 12 most abundant species, which is more than $70 \%$ of the isolates recovered, in 2012 were also within the top 12 species recovered in 2011. The most abundant species in 2012 were P. sylvaticum (14.5\%), P. heterothallicum (12.2\%), Phytophthora sojae (9.3\%), P. ultimum var. ultimum $(6.1 \%)$, P. perplexum $(6.0 \%)$, P. irregulare (5.8\%), P. oopapillum (3.2\%), P. inflatum (2.9\%), P. attrantheridium $(2.7 \%)$, P. intermedium $(2.7 \%), P$. rostratifingens $(2.6 \%)$, and P. ultimum (2.5\%) (Fig. 2). Other genera recovered from soybean seedlings that were outside the scope of this study included members of the fungal genera Mortierella, Mucor, Gongronella, Rhizoctonia, and the mycoparasite genus Laetisaria.

Among the 84 species isolated in this study, only 13 species were previously reported to be associated with soybean in the United States Department of Agriculture-Agricultural Research Service (USDA-ARS) fungal-host database (http://nt.ars-grin. gov/fungaldatabases/fungushost/fungushost.cfm), including the well-known pathogen Phytophthora sojae. The isolation frequency of Phytophthora sojae at the early plant-growth stage sampled was $0.5 \%$ in 2011 . A second semiselective medium was included in 2012, in an attempt to increase the recovery of Phytophthora sojae and other Phytophthora species. In 2012, the recovery of Phytophthora spp. increased to $12 \%$ when different 
methods (different medium and numbers of plants per medium) were used. The frequency of Phytophthora spp. increased but still remained low in comparison with genus Pythium. The low recovery could be attributed to recovery of fast-growing species, such as Pythium and Mortierella spp., that interfere with the isolation of Phytophthora spp. (Tsao and Guy 1977).
Summarizing the data by clade (Fig. 3), Pythium clades F (36\% in 2011 and 26\% in 2012) and B (23\% in 2011 and 13\% in 2012) were the most abundant clades isolated during this study. These clades contain known pathogenic species such as $P$. sylvaticum and $P$. irregulare in clade F and $P$. oopapillum and $P$. torulosum in clade B. With respect to Phytophthora, clade 7 was present at a frequency

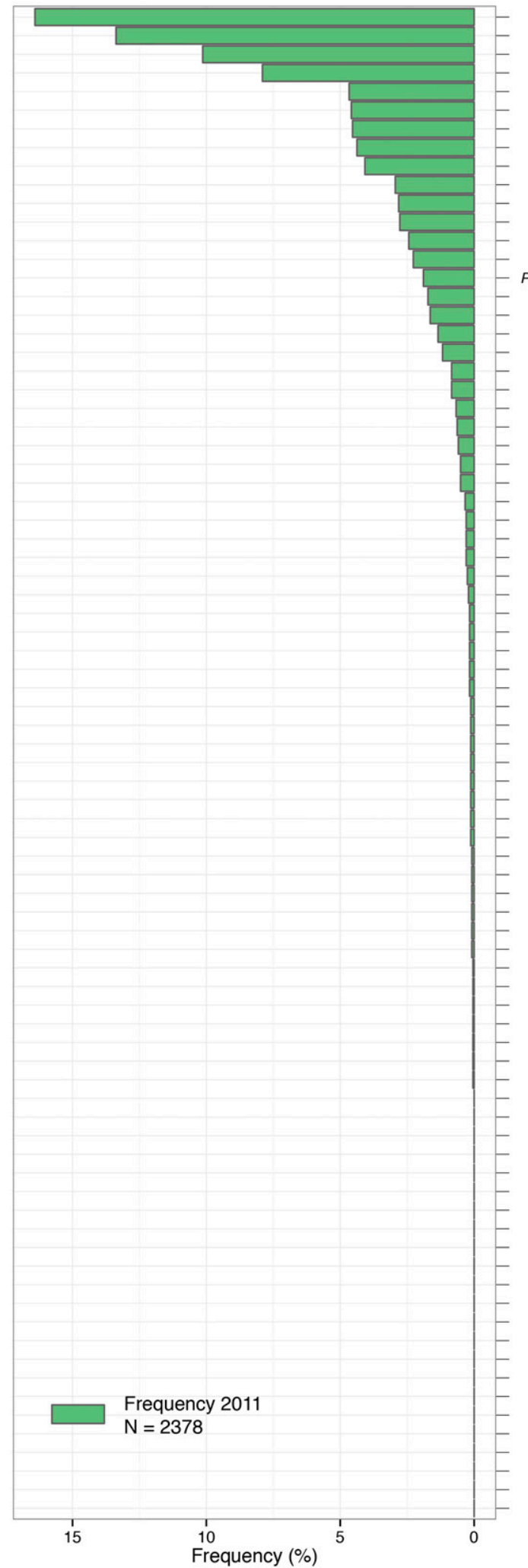

Pythium sylvaticum* Pythium oopapillum Pythium irregulare* Pythium heterothallicum Pythium aff. torulosum* Pythium spinosum ${ }^{*}$ Pythium ultimum var. ultimum* Pythium aff. dissotocum ${ }^{*}$ Pythium lutarium Pythium paroecandrum Pythium attrantheridium* Pythium ultimum Pythium sp. Pythium inflatum Pythium ultimum var. sporangiiferum Pythium perplexum Pythium rostratifingen Pythium acanthicum Pythium nodosum Pythium sp. balticum Pythium coloratum Pythium pachycaule Pythium orthogonon Pythium orthogonon
Pythium pleroticum Pythium conidiophorum Phytophthora sojae* Pythium aff. perplexum Pythium rhizosaccharum Pythium intermedium Pythium aphanidermatum Pythium middletonii Pythium glomeratum Pythium nunn Pythium nagaii Pythium minus Pythium aff. diclinum Phytopythium litorale Pythium tardicrescens Pythium monospermum Pythium monospermum
Pythium longisporangium Pythium longandrum Pythium kashmirense Pythium hypogynum Pythium amasculinum Phytophthora sansomeana* Pythium torulosum Pythium periplocum Pythium kunmingense Phytopythium chamaehyphon Pythium arrhenomanes Pythium aff. dictyosporum Pythium catenulatum Pythium carolinianum Pythium adhaerens Pythium adhaerens
Pythium acrogynum Phytopythium helicoides Phytophthora inundata Aphanomyces cochlioides Pythium vanterpoolii

Pythium terrestris Pythium sterilum Pythium pyrilobum Pythium oligandrum * Pythium hydnosporum Pythium cryptoirregulare Pythium contiguanum Pythium chondricola Pythium camurandrum Pyun camurandrum Pythium angustatum Pythium aff. iwayamai Pythium aff. hypogynum Pythium acanthophoro Pythiogeton sp. Phytopythium mercuriale Phytopythium megacarpum Phytopythium aff. vexans Phytophthora $s p$.
Phtopythium aff. vexpur Phytophthora rosacearum Phytophthora megasperma Phytophthora aff. rosacearum

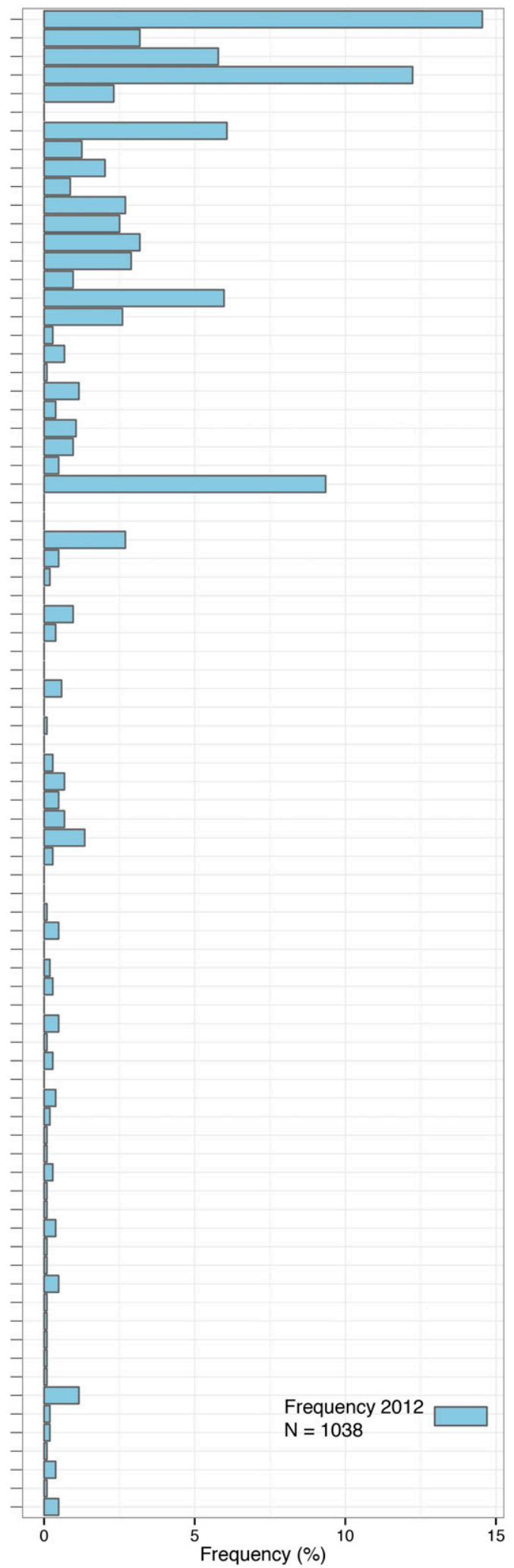

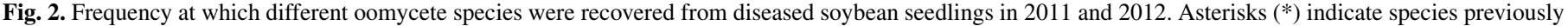
reported as associated with soybean in the USDA-ARS fungal-host database (http://nt.ars-grin.gov/fungaldatabases/fungushost/fungushost.cfm). 
of $1 \%$ in 2011 and $4 \%$ in 2012, and clade 8 at $<1 \%$ in 2011 and $3 \%$ in 2012. Phytophthora clades 7 and 8 contain the species Phytophthora sojae and $P$. sansomeana, respectively. The recently recognized genus Phytopythium was recovered at a lower frequency with respect to the other related genera and was detected at just

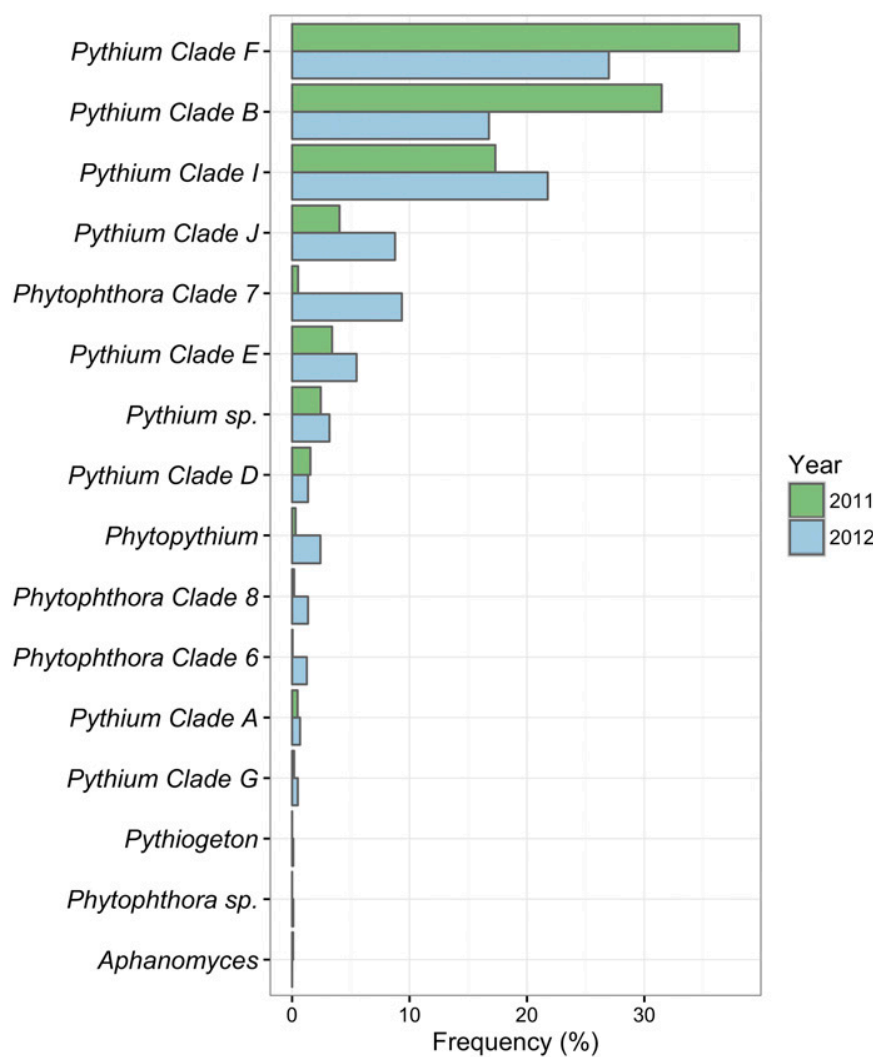

Fig. 3. Frequency of the oomycete species summarized by clade for 2011 and 2012. Oomycete genera outside of Pythium and Phytophthora were summarized by genus. Those species designated as spp. are not well-resolved, based only on the internal transcribed spacer sequence.
$1 \%$ and 3\%, respectively, in 2011 and 2012 (Fig. 2). There were 91 isolates designated as Pythium spp. that were not resolved to species level, but these are currently under further evaluation.

Seed pathogenicity. The main goal of this assay was to determine which species were pathogenic to soybean (i.e., resulting in significant seed rot compared with a noninoculated control) at temperatures representative of planting conditions in the northern and southern United States. The seed-rot assay at $20^{\circ} \mathrm{C}$ identified 11 species that were pathogenic, with DSI scores ranging from 80 to a maximum score of 100 (Table 1; Supplementary Table S2). Among the species observed, $P$. aphanidermatum, $P$. ultimum sensu lato, and $P$. cryptoirregulare were the most virulent and caused severe seed rot. In addition to Pythium spp., Phytophthora sansomeana, Phytophthora drechsleri, and Phytopythium helicoides were also pathogenic on soybean seed, colonizing the seed and causing significantly reduced germination at $20^{\circ} \mathrm{C}$.

Evaluation of seed rot at $13^{\circ} \mathrm{C}$ identified 13 Pythium spp. as pathogenic, with DSI scores ranging from 78 to a maximum score of 100 (Table 1). However, none of the Phytophthora or Phytopythium spp. was identified as being pathogenic at this temperature, typical of planting conditions in the Midwest. Only seven Pythium spp. were pathogenic at both temperatures, with P. ultimum sensu lato and $P$. cryptoirregulare being the most virulent. However, there were shifts in virulence observed among oomycete species at the different temperatures. For instance, $P$. sansomeana, $P$. drechsleri, and Phytopythium helicoides showed less virulence at $13^{\circ} \mathrm{C}$ than $20^{\circ} \mathrm{C}$ (Fig. 4; Table 1), while P. sylvaticum, P. terrestris, and P. paroecandrum appeared more virulent at 13 but not at $20^{\circ} \mathrm{C}$.

Due to the large range of virulence responses, disease severity indices at 13 and $20^{\circ} \mathrm{C}$ were compared using a hierarchical clustering to group oomycete species, which resulted in three defined clusters (Supplementary Fig. S1). Cluster A represents all species that did not have a negative effect on seed germination. Cluster B contains species with virulence that were not significantly different from the control but still caused reduced seed health, expressed as DSI. Cluster C includes highly virulent species that were significantly different from the control and two species that were not significantly different from the control, $P$. lutarium and $P$. coloratum, which had DSI scores at $13^{\circ} \mathrm{C}$ of 62.7 and 49.3 and at $20^{\circ} \mathrm{C}$ of 71.7 and 49.6 , respectively.

TABLE 1. Mean disease severity index (DSI) of soybean cv. Sloan seeds in response to multiple oomycete species as compared with the noninoculated control at $13^{\circ} \mathrm{C}$ or $20^{\circ} \mathrm{C}^{\mathrm{a}}$

\begin{tabular}{|c|c|c|c|c|c|}
\hline \multirow[b]{2}{*}{ Species } & \multirow[b]{2}{*}{ No. ${ }^{b}$} & \multicolumn{2}{|c|}{ Disease index $(\%) 13^{\circ} \mathrm{C}^{\mathrm{c}}$} & \multicolumn{2}{|c|}{ Disease index $(\%) 20^{\circ} \mathrm{C}$} \\
\hline & & Mean \pm SE & $P$ value & Mean \pm SE & $P$ value \\
\hline Phytophthora drechsleri & 1 & $13.06 \pm 3.19$ & NS & $90.28 \pm 2.02$ & 0.049 \\
\hline Phytophthora sansomeana & 2 & $58.89 \pm 10.01$ & NS & $94.72 \pm 1.31$ & 0.004 \\
\hline Pythium aff. diclinum & 3 & $78.70 \pm 2.50$ & 0.032 & $32.96 \pm 5.28$ & NS \\
\hline P. aff. dictyosporum & 2 & $93.33 \pm 1.14$ & 0.006 & $85.14 \pm 4.22$ & 0.017 \\
\hline P. aphanidermatum & 3 & $53.24 \pm 3.82$ & NS & $99.91 \pm 0.09$ & $<0.001$ \\
\hline P. irregulare & 3 & $98.89 \pm 0.45$ & 0.001 & $80.46 \pm 3.53$ & 0.027 \\
\hline P. kunmingense & 2 & $100.00 \pm 0.00$ & 0.002 & $89.31 \pm 1.50$ & 0.007 \\
\hline P. paroecandrum & 3 & $93.98 \pm 1.64$ & 0.002 & $49.26 \pm 4.37$ & NS \\
\hline P. spinosum & 3 & $80.56 \pm 4.12$ & 0.023 & $44.72 \pm 7.00$ & NS \\
\hline P. sylvaticum & 3 & $99.44 \pm 0.24$ & 0.001 & $74.44 \pm 2.64$ & NS \\
\hline P. terrestris & 1 & $99.17 \pm 0.59$ & 0.021 & $77.78 \pm 3.42$ & NS \\
\hline P. ultimum & 3 & $99.17 \pm 0.30$ & 0.001 & $99.26 \pm 0.32$ & $<0.001$ \\
\hline
\end{tabular}

a Only species with significant differences from the control at either temperature are represented. A seed-rot assay was used to determine pathogenicity of oomycete species using a disease severity scale of $0-4$ to rate individual seeds. Data were transformed to DSI $(0=$ nonpathogenic; $100=$ highly virulent $)$. A total of 84 species were tested at both temperatures.

${ }^{b}$ Number of isolates tested per species.

${ }^{c} \mathrm{SE}=$ standard error. $P$ value based on Dunnett's test, significantly different from the non-rice control $(\alpha=0.05)$; NS $=$ not significant. 
Seedling root-rot assay. Five parameters were measured to determine which species were detrimental to growth of soybean seedlings: root dry weight, shoot dry weight, shoot/root ratio, root area, and root length. Using PCA, the five parameters were evaluated for their contribution in the discrimination of the different species. All of the parameters measured showed differences between the inoculated treatments and the noninoculated controls (Supplementary Figs. S2 and S3). The analysis showed that root area, root length, and weight per root had the greatest contribution in separating the species in PCA 1, explaining $67.7 \%$ of the variability observed in the data. Shoot dry weight and shoot/root ratio contributed only 13 and $18 \%$ of the variability, respectively. Therefore, shoot dry weight and shoot/root ratio were not used in further analyses. The other three parameters had high correlation values (weight per root, $r^{2}=0.955, P \leq 0.001$; root length, $r^{2}=0.934$, $P \leq 0.001$; root area, $r^{2}=0.921, P \leq 0.001$ ) with the first dimension of the PCA, while the shoot dry weight correlation was lower $\left(r^{2}=\right.$ 0.730).

Based on the PCA results, a MANOVA analysis was conducted, using the three parameters: root area, root length, and weight per root (Supplementary Fig. S4). Dunnett's test identified 43 oomycete species as significantly different from the non-rice control. In addition, the noninoculated control was not significantly different from the non-rice control. These parameters had a negative effect on the combined parameters measured on the soybean seedlings
(Table 2). In order to determine the contribution of each variable and further explore the results obtained in the MANOVA analysis, univariate analyses were performed on the three parameters, root dry weight, root length, and root area. The univariate analysis for root area showed similar results to the MANOVA analysis, resulting in 43 species with a significant effect on seedlings when compared with the non-rice control. A total of 21 oomycete species were determined to have a significant detrimental effect on seedlings across the multivariate and univariate analyses (Table 2).

Of the 21 pathogenic species across the multivariate and univariate analyses, the Phytophthora spp. Phytophthora sojae, Phytophthora sansomeana, and Phytophthora drechsleri were the most virulent, causing significant root reduction or death of radicles. The remaining pathogenic species belonged in the genus Pythium, and most species were within clade F (P. cryptoirregulare, $P$. irregulare, $P$. sylvaticum, $P$. attrantheridium, $P$. intermedium, and $P$. kunmingense) and clade B ( $P$. aff. dissotocum, $P$. aff. torulosum, $P$. aff. diclinum, $P$. aff. dictyosporum, $P$. lutarium, and $P$. oopapillum). Clades with lower numbers of species found during this study were also designated as pathogenic based on our analysis, like Pythium clade I ( $P$. heterothallicum, $P$. ultimum sensu lato), clade D (P. periplocum), and Aphanomyces cladogamus. All of the Phytophthora, Pythium, and Aphanomyces isolates evaluated caused a considerable reduction in root development and, in some cases, death of the radicle as well (Supplementary Fig. S5).

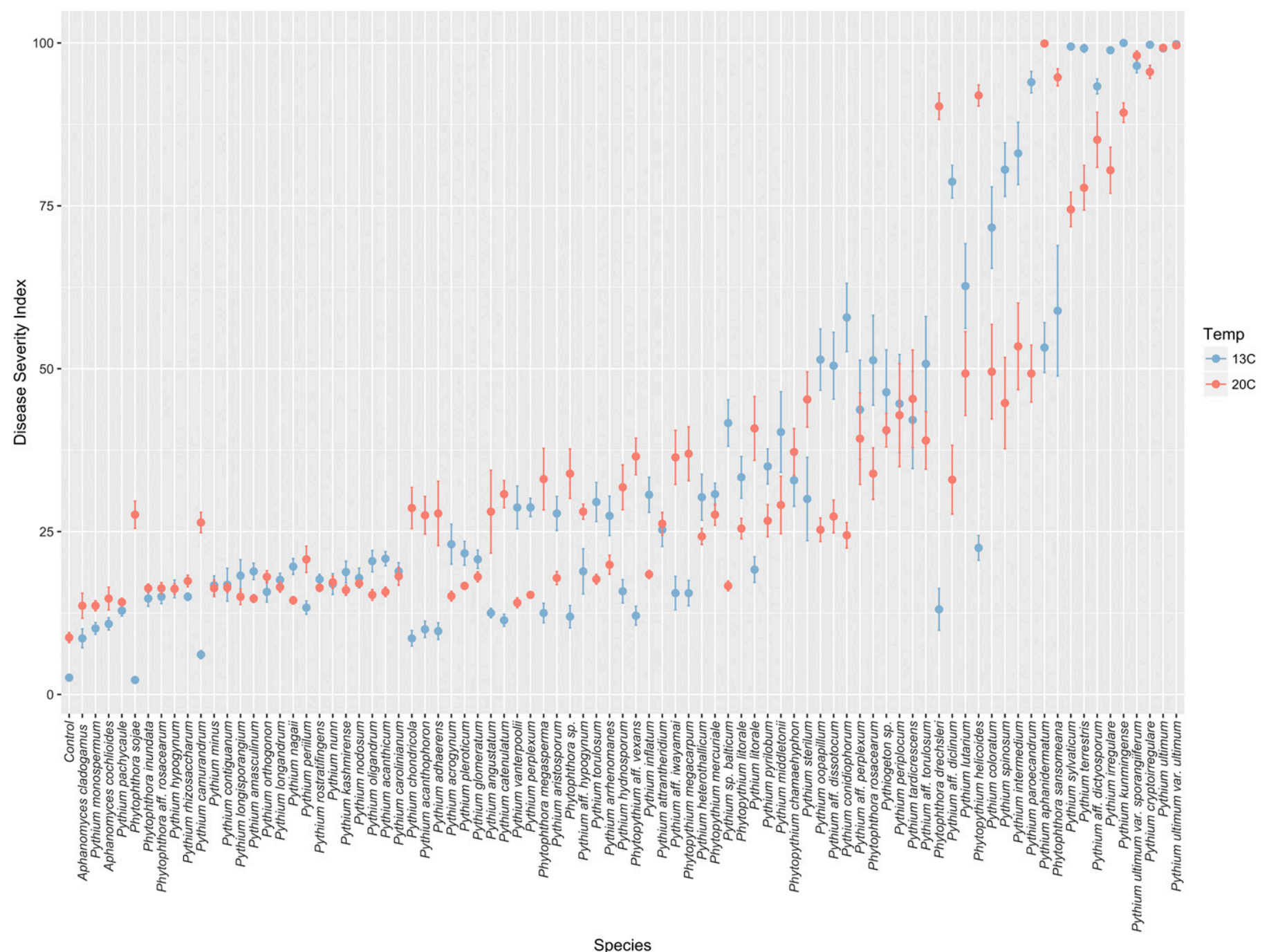

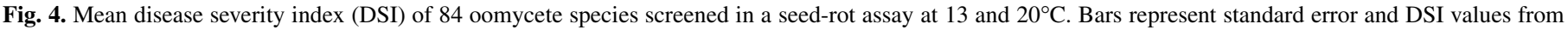
$0=$ nonpathogenic to $100=$ highly virulent. 
Of the 43 species that were significantly different from the nonrice control in the MANOVA analysis, there were 22 species that were significant in only two or one of the univariate analyses, including members of the Pythium clades B, F, I and E as well as different species of genera Phytopythium and Aphanomyces (Table 2).

The remaining 41 oomycete species did not have a significant effect on seedlings, based on root area, root length, and dry weight per root (Supplementary Table S3). Interestingly, Pythium Clade B, which contains most of the pathogenic species, also included nonpathogenic species (P. inflatum, $P$. catenulatum, $P$. angustatum). In addition to clade $\mathrm{B}$, other clades were also represented, including Pythium clade E (P. acrogynum, P. middletonii, P. pleroticum), clade $\mathrm{J}$ ( $P$. perplexum, $P$. nodosum, $P$. orthogonon), and clade D
(P. amasculinum, P. oligandrum, $P$. acanthicum) (Fig. 5). Among the less-frequent nonpathogenic species, Pythium clade $\mathrm{F}$ and A were represented with three species each and clade I and $G$ with one species each. Apart from Pythium spp., three species from Phytophthora clade 6 were nonpathogenic, followed by two Phytopythium spp. and one species of the genus Pythiogeton.

Koch's postulates were completed by reisolation from inoculated seedlings and identification of isolates via SSCP. All of the species designated as pathogenic on the seedlings were isolated and confirmed by SSCP, having two or more successful isolation events. Of the nonpathogenic species, most of the species used in the seedling cup assay were recovered at least once, except Phytophthora megasperma, $P$. adhaerens, and $P$. chondricola, which we failed to reisolate.

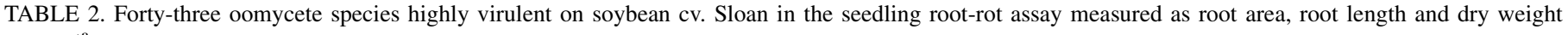
per root ${ }^{\mathrm{a}}$

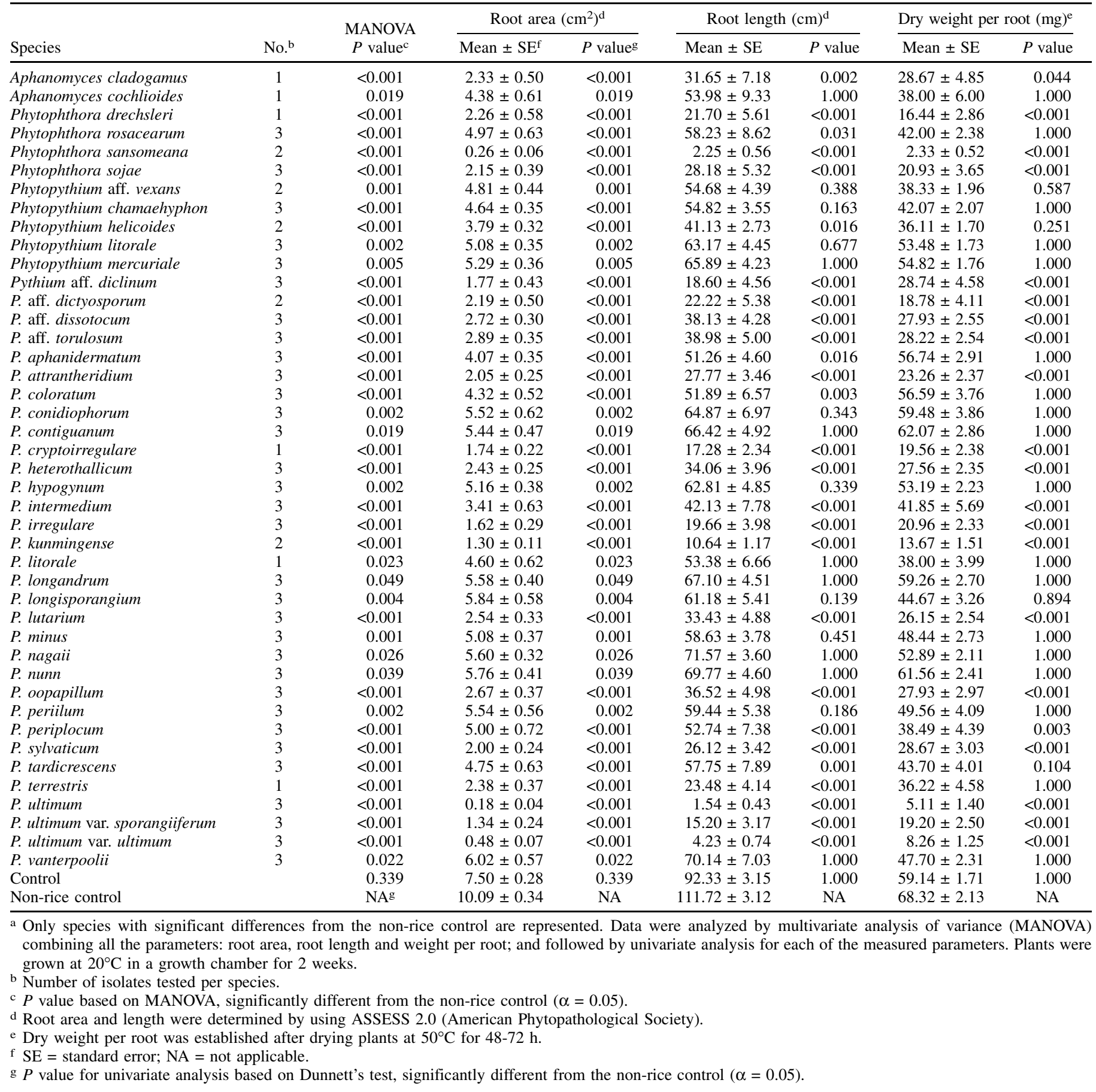


Comparison of seed and seedling root-rot assays. Among the species evaluated, $P$. paroecandrum and $P$. spinosum were the only species that caused seed rot and did not cause significant damage to plants in the seedling assay. The remaining species determined to be pathogenic with the seed-rot assay were also identified as pathogenic with the seedling assay (Fig. 5). Among the species pathogenic on seed and seedling, P. terrestris, P. aphanidermatum, and Phytopythium helicoides were the only species that were not significant for root weight univariate analysis, the rest of species were significant for all analyses. Taking
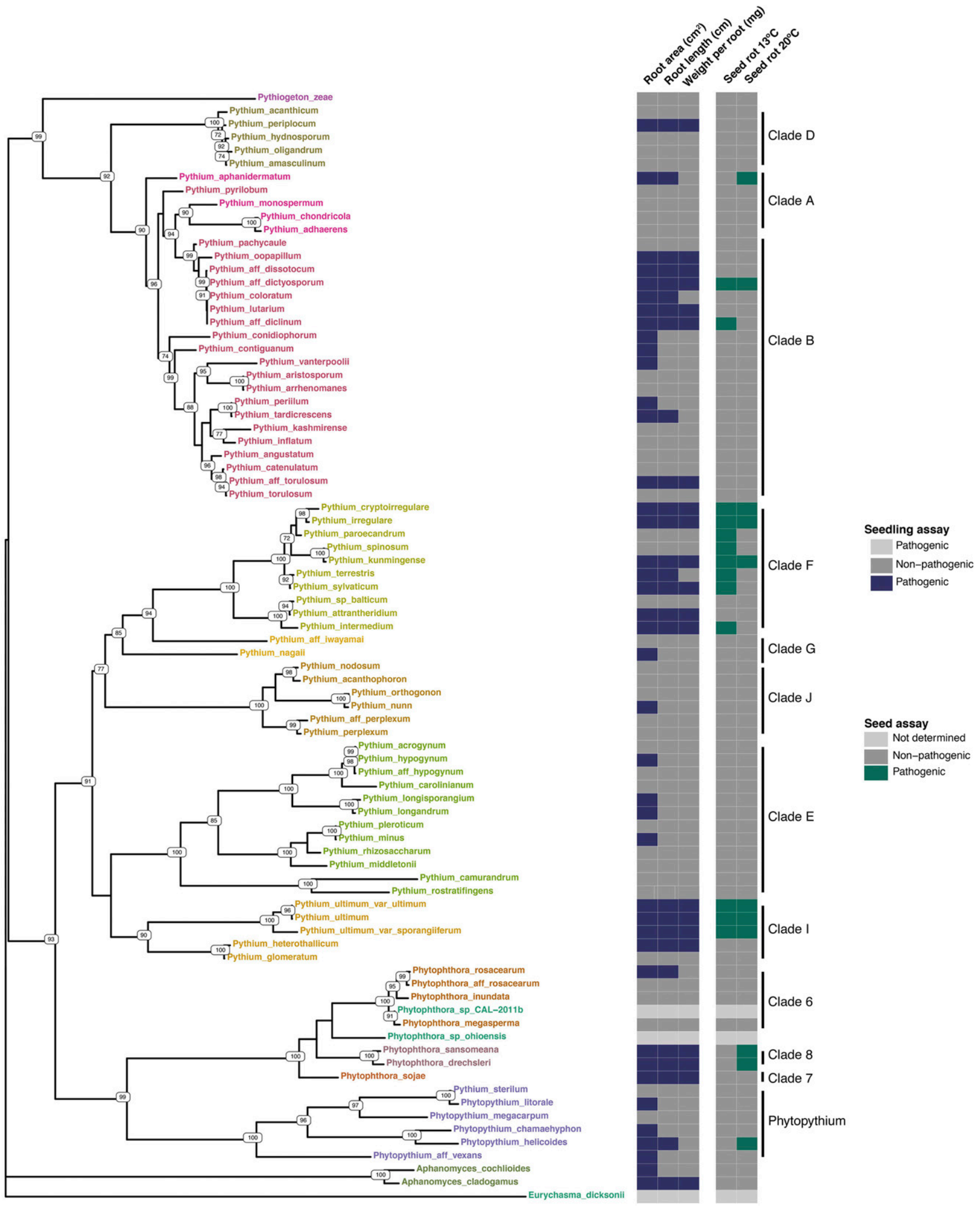

Fig. 5. Maximum likelihood phylogeny of the internal transcribed spacer sequences of the rDNA for oomycete species found during the survey. Numbers on the branches indicated bootstrap values for 1,000 replicates $(>70)$. Phylogenetic distribution of pathogenicity traits mapped to taxa represented in the tree. Tip shades indicate members of different clades. Parameters in light gray represent taxa not isolated in the study. 
pathogenicity into account, the prevalence of these species was evaluated by state, using the data from the survey (Fig. 6). The species $P$. sylvaticum, $P$. heterothallicum, $P$. ultimum sensu lato, $P$. oopapillum, and $P$. aff. dissotocum were pathogenic and also prevalent across most states sampled during the survey (Fig. 6). Among the nonpathogenic species under the conditions of this study, $P$. perplexum, $P$. rostratifingens, and $P$. inflatum were the most prevalent across the sampled states.

\section{DISCUSSION}

The current study was undertaken to acquire a greater understanding of the oomycete communities associated with and potentially involved in soybean seedling diseases across the major United States soybean-producing states and Ontario, Canada. A total of 84 oomycete species were identified out of 3,416 isolates collected primarily from diseased soybean seedlings over the years 2011 and 2012. The 84 species belonged to the genera Pythium (94.85\%), Phytophthora (4.15\%), Phytopythium (0.91\%), Aphanomyces $(0.06 \%)$, and Pythiogeton $(0.03 \%)$. Of the 84 species, 43 were determined to be pathogenic to seeds or seedlings, with the majority of isolates being pathogenic to both seeds and seedlings. The majority of the isolates recovered were pathogenic on soybean belonging to Pythium clades F, B, and I, which are known to contain the majority of pathogenic Pythium species (Lévesque and De Cock 2004).

Between years 2011 and 2012, the number of isolates changed considerably, despite using the same sampling approach. In 2011, a total of 2,380 isolates were collected, whereas in 2012 only 1,038 were collected. The difference in recovery of oomycetes could be due to the drought and temperature differences between years. For instance, in 2011, in the midwestern United States, from April to June, $5 \%$ of the region was identified as experiencing moderate drought conditions, with an additional $3.5 \%$ ranked as abnormally dry. However, from April to June in 2012, by comparison, $18 \%$ of the region experienced moderate drought and $47 \%$ was classified as abnormally dry (http://droughtmonitor.unl.edu/). The average environmental temperature in this same region for the period from April to June in 2011 was $16^{\circ} \mathrm{C}$ and in 2012 was $18^{\circ} \mathrm{C}$ (http://www. ncdc.noaa.gov/temp-and-precip/climatological-rankings). These dry conditions could have impacted the recovery of species due to reduced infection, since soil water serves as a carrier for chemical root stimulants and provides conditions for oospore germination, sporangia formation, and zoospore locomotion (Martin and Loper 1999).

One of the goals of the second year was to increase the number of Phytophthora spp. recovered; therefore, a second medium was included to improve recovery. The medium was amended with hymexazol to inhibit Pythium spp.; however, it is known that it can also affect some Phytophthora spp. (Jeffers 1986). In general, the V8-RPBH medium reduced the recovery of Pythium spp., but a small percentage of isolates were still recovered from most Pythium clades (Supplementary Fig. S6). Aiming to increase the recovery of Phytophthora spp., samples were plated into two different medium that could also affect the number of oomycetes recovered, in addition to the other environmental factors mentioned above. The

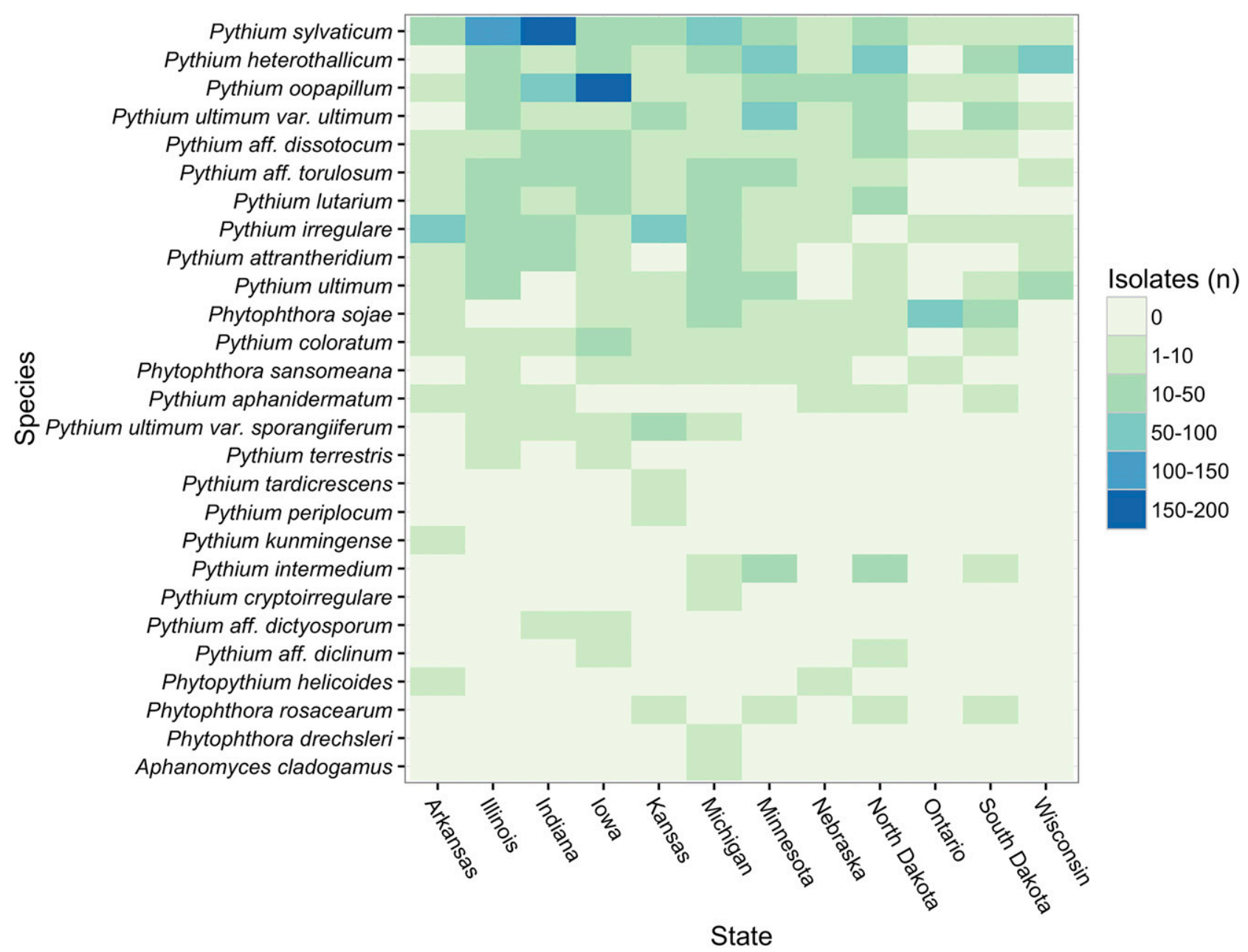

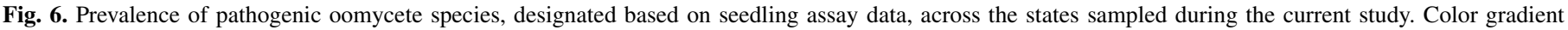
indicates number of isolates per species collected per state during 2011 and 2012. 
medium did increase the recovery of Phytophthora spp., but the numbers in comparison with those of Pythium spp. were still low. The frequency of isolation of Phytophthora spp. is affected by fast-growing species, such as members of genera Pythium and Mortierella, which can still be recovered in the presence of hymexazol (Tsao and Guy 1977). In Phytophthora clade 7, which contains Phytophthora sojae, recovery increased $20 \%$ on the V8RPBH medium in comparison with the CMA-PARPB medium. Interestingly, this medium also increased the recovery of other genera such as Phytopythium and Pythiogeton. Ontario showed a biased recovery of Phytophthora sojae due to modification in the isolation protocol, which utilized baiting and modified conditions such as soil moisture saturation, to increase the recovery of this pathogen.

Previous surveys examining the diversity of Pythium spp. associated with symptomatic soybeans characterized a range of 11 to 27 different species present in individual states (Broders et al. 2007, 2009; Zitnick-Anderson and Nelson 2015). Most species found in this multistate survey were in agreement with other studies that focused on soybean root rot, including common species such as $P$. ultimum sensu lato, $P$. sylvaticum, and $P$. irregulare. However, other species such as $P$. echinulatum and $P$. graminicola were not isolated during our survey but have been reported from soybean fields in Ohio (Broders et al. 2007). In North Dakota, an extensive survey reported similar species to the ones found in our study, especially the most abundant species like P. ultimum, P. heterothallicum, and $P$. sylvaticum. However, there were differences in the least abundant species, as indicated by $P$. debaryanum and $P$. violae, which were not recovered in our study (Zitnick-Anderson and Nelson 2015). Other studies in which the soil and the rhizosphere of soybean fields were sampled in order to characterize Pythium spp. recovered species similar to the ones in our study (Jiang et al. 2012; Marchand et al. 2014).

Previous studies have demonstrated the potential for multiple oomycete species to be present within a single root system of soybean plants (Broders et al. 2007; Zitnick-Anderson and Nelson 2015). It is important to distinguish which of the multiple oomycete species may have a detrimental effect on the root system. Seed rot and seedling root-rot assays have been used in several studies to characterize the pathogenicity of oomycete species. Broders et al. (2007) used two different assays to evaluate the pathogenicity of several Pythium spp. to corn and soybean. These assays have been used in various studies to evaluate the pathogenicity and virulence of oomycete species (Matthiesen et al. 2016; Zitnick-Anderson and Nelson 2015) in which both seed rot and seedling assays were scored using a qualitative visual assessment. In this study, we used both assays. However, for the seedling assay, quantitative data were collected using dry weights and software image analysis to quantify root area and root length, in order to measure the effect of the potential pathogenic species on soybean seedlings. Based on our results, root area was the most informative parameter to identify a greater number of pathogenic species. Similar approaches, including the determination of root area and dry weight of roots and shoots, have been used to characterize root-rot pathogens on cucurbits and other plants (Biernacki and Bruton 2001; Bock et al. 2010; Higginbotham et al. 2004).

The 84 oomycete species identified in this study were characterized for pathogenicity and virulence using a subset of up to three isolates per species for pathogenicity on seed and seedlings. Overall, the variability of virulence per species was low, but further characterization of more isolates, particularly with species such as $P$. lutarium and $P$. aff. torulosum, is needed. This variability is expected in some species, due to the degree of genetic diversity and potential species complexes, as was reported for $P$. ultimum (Higginbotham et al. 2004). The seedling assay based on quantitative measurements captured a broad range of effects of the different species in a susceptible cultivar of soybean, identifying 43 species as pathogenic with different levels of virulence. A total of 21 species had a detrimental effect in reducing all parameters measured, and the remaining 22 species reduced either one or two of the parameters, as compared with the non-rice control (Fig. 5). Most of the species identified as seedling pathogens were also characterized as seed pathogens. Only P. paroecandrum and $P$. spinosum caused seed rot at $13^{\circ} \mathrm{C}$ but did not cause root rot on seedlings. The remaining 41 of the 84 oomycete species did not significantly increase root rot compared with the control and were designated as nonpathogenic.

Environmental conditions often influence the outcome of the interaction of different Pythium spp. with soybean seedlings, since it has been observed that different species have temperaturemediated virulence (Matthiesen et al. 2016). In our study, this was observed in the seed-rot assay, where multiple species had a virulence shift based on temperature, being more virulent at either low or high temperatures. Similar behavior was reported for P. torulosum on seeds and seedlings, being nonpathogenic or having reduced virulence at temperatures of 18 and $23^{\circ} \mathrm{C}$ but increased virulence at $13^{\circ} \mathrm{C}$ (Matthiesen et al. 2016). The $\mathrm{pH}$ can also impact virulence; for instance, $P$. debaryanum is more virulent below $\mathrm{pH}$ 6.6, and some species increase their saprophytic activity around pH 7 (Martin and Loper 1999).

It has been suggested that plants infected with Pythium spp. have reduced vigor (Gilbert 2002; Paulitz et al. 2002; Pieczarka and Abawi 1978). The reduced vigor is often observed as stunted plants, necrotic root lesions, and leaf yellowing (Kirkpatrick et al. 2006). Therefore, measuring various root parameters is an approach to characterize and parse the effects of different species on the root system of soybean plants. The use of two controls, one with noninoculated rice and one of a non-rice control, were intended to rule out any negative effects of rice by itself on seedling and root development. However, we did not see statistical differences between the two controls in any of the tests conducted. Some of the species designated as nonpathogenic produced lesions in the seedlings but, based on the statistical analysis, their effect was negligible when compared against a non-rice control. Although several of the species were nonpathogenic in the assays used, it is possible that they may not have fully expressed their virulence due to the lack of certain conditions, such as temperature, $\mathrm{pH}$, or interaction with other organisms (Becker et al. 2012; Littrell and McCarter 1970; Mondal and Hyakumachi 2000). On the other hand, the designation of nonpathogenic species based on our analysis also overlapped with the previous reports in which species like $P$. nunn, $P$. orthogonon, and P. torulosum, among others, did not cause significant symptoms on soybean plants (Zitnick-Anderson and Nelson 2015). Some of these species have been reported as mycoparasites or competitors. This is the case with $P$. nunn, which has niche overlap with $P$. ultimum, being a colonizer of organic matter without causing plant disease and parasitizing hyphae (Martin and Loper 1999). Therefore, the isolation of these species could be the result of niche overlap or these species could be parasitizing certain pathogenic Pythium spp. In addition, some of the species in our study resulted in observable (not significant) positive effects on the root parameters, resulting in values higher than the control. It has been observed that $P$. oligandrum and other Pythium spp. produced auxinlike products that could increase root formation or cause irregular root development (Le Floch et al. 2003).

Several of the species reported as pathogens in the USDAARS fungal-host database and reported here were prevalent in most of the states surveyed, including $P$. sylvaticum, $P$. heterothallicum, and P. oopapillum (Fig. 6). The species were present in most states, but their abundance varied across the different fields. Other pathogenic species were less prevalent but still present in low numbers in more than four states; such is the case with $P$. ultimum, $P$. aff. dissotoccum, and $P$. aff. torulosum. In regards to Phytophthora spp., both Phytophthora sojae and $P$. sansomeana were recovered in low numbers in most states; however, this could be an artifact of sampling method and timing. 
Due to the large number of isolates recovered in the study, we utilized ITS sequencing and BLASTn searches against a curated set of sequences recently compiled by Robideau et al. (2011) and sequences deposited in the Consortium for the Barcode of Life database (www.barcoding.si.edu/). Previous studies have utilized SSCPs or a combination of morphological and sequence data for species identification. However, the resolution at species level of SSCPs is limited, since it may not always capture the diversity, as the region utilized is not informative for all species. Although, conducting SSCPs is cost effective, it does require the use of isolate standards or the additional sequencing or morphological identification of those isolates resulting in unique SSCP patterns. Sequence data provides an easily searchable and archive-ready data format. However, caution should be exercised when searching against the GenBank DNA sequence database, as the sequences are not highly curated and there is a high error rate in species labels (Kang et al. 2010). Zitnick-Anderson and Nelson (2015) used sequencing of the rDNA aided by morphological characterization of Pythium spp., which helped correct some of the molecular misidentifications based on poor sequence data in GenBank. It has been discussed previously that one gene might not reflect the species boundaries and caution should be used when setting a blast threshold (Kang et al. 2010). However, some precautionary measures can be used to reduce error, such as the length of the alignment and the database used. The ITS of rDNA and cytochrome c oxidase subunit I have been designated as barcodes for the oomycetes and, in some cases, either barcode gene is not enough to resolve some species, but these regions do have the most complete set of curated sequences and, if possible, sequencing both barcodes typically increases the confidence of the species designation (Kang et al. 2010; Robideau et al. 2011).

Previous to this study, a total of 24 oomycete species had been reported as root pathogens of soybean, 16 of which were also isolated in our study. In the present study, we report 13 oomycete species that are pathogens of soybean causing a detrimental effect on seedling roots that have not previously been associated with this crop. These included $P$. drechsleri, $P$. cryptoirregulare, $P$. kunmingense, $P$. periplocum, $P$. conidiophorum, $P$. longisporangium, $P$. contiguanum, $P$. vanterpoolii, P. nagaii, $P$. longandrum, Phytopythium aff. vexans, Phytopythium litorale, and Aphanomyces spp. However, the number of reported pathogenic species could be higher, but we are assuming that the affinity species were overlooked due to the lack of sequence resources to clearly identify this species and have previously been reported as the actual species. These include $P$. aff. diclinum, $P$. aff. dictyosporum, $P$. aff. dissotocum, and $P$. aff. torulosum, which were collected and characterized as pathogenic/virulent under this study's conditions. The current study provides an overview of characteristics and prevalence of the different oomycete species associated with seedling diseases in the major soybean-producing states. The diversity of species identified and characterized provides a valuable resource for the testing of different management strategies, evaluating fungicide resistance, and in selecting a pool of candidate pathogens to aid breeding programs focused on screening for resistance to oomycete pathogens.

\section{ACKNOWLEDGMENTS}

This project was supported by Agriculture and Food Research Initiative Competitive grant number 2011-68004-30104 from the USDA National Institute of Food and Agriculture, and Project GREEEN \#GR11-081. The project was also supported in part by the United Soybean Board and North Central Soybean Research Program. Ontario participation was supported by the Grain Farmers of Ontario, who obtained funding, in part, through 'Growing Forward 2' (GF2), a federal-provincial-territorial initiative. The Agricultural Adaptation Council assists in the delivery of GF2 in Ontario. We thank the following personnel who made this project possible: T. Welacky (Ontario), T. Anderson (Ontario), C. Van Herk (Ontario), G. Kotulak (Ontario), G. Stasko (Ontario), A. Steger (Arkansas), R. Holland (Akansas), K. Urrea (Akansas), N. Anderson (Indiana), J. Ravellette
(Indiana), R. Matthiesen (Iowa), V. Silva (Iowa), D. Pedersen (Illinois), U. Reuter-Carlson (Illinois), J. O'Mara (Kansas), B. Grabow (Kansas), B. McKinzie (Kansas), C. Floyd (Minnesota), and C. Groves (Wisconsin). Also, we thank F. Martin for the helpful discussions.

\section{LITERATURE CITED}

Altschul, S. F., Gish, W., Miller, W., Myers, E. W., and Lipman, D. J. 1990. Basic local alignment search tool. J. Mol. Biol. 215:403-410.

Anderson, T. R. 1987. Fungi isolated from stems and roots of soybean in Ontario. Can. Plant Dis. Surv. 67:3-5.

Becker, J., Eisenhauer, N., Scheu, S., and Jousset, A. 2012. Increasing antagonistic interactions cause bacterial communities to collapse at high diversity. Ecol. Lett. 15:468-474.

Biernacki, M., and Bruton, B. D. 2001. Quantitative response of Cucumis melo inoculated with root rot pathogens. Plant Dis. 85:65-70.

Bock, C. H., Poole, G. H., Parker, P. E., and Gottwald, T. R. 2010. Plant disease severity estimated visually, by digital photography and image analysis, and by hyperspectral imaging. Crit. Rev. Plant Sci. 29: 59-107.

Broders, K. D., Lipps, P. E., Paul, P. A., and Dorrance, A. E. 2007. Characterization of Pythium spp. associated with corn and soybean seed and seedling disease in Ohio. Plant Dis. 91:727-735.

Broders, K. D., Wallhead, M. W., Austin, G. D., Lipps, P. E., Paul, P. A., Mullen, R. W., and Dorrance, A. E. 2009. Association of soil chemical and physical properties with Pythium species diversity, community composition, and disease incidence. Phytopathology 99:957-967.

Cooke, D. E., Drenth, A., Duncan, J. M., Wagels, G., and Brasier, C. M. 2000. A molecular phylogeny of Phytophthora and related oomycetes. Fungal Genet. Biol. 30:17-32.

Dorrance, A. E., Berry, S. A., Anderson, T. R., and Meharg, C. 2008. Isolation, storage, pathotype characterization, and evaluation of resistance for Phytophthora sojae in soybean. Plant Health Prog. doi:10.1094/PHP-20080118-1001-DG

Dorrance, A. E., Kurle, J. E., Robertson, A. E., Bradley, C., Giesler, L., Wise, K. A., and Concibido, V. C. 2016. Pathotype diversity of Phytophthora sojae in eleven states in the United States. Plant Dis. 100:1429-1437.

Erwin, D. C., and Ribeiro, O. K. 1996. Phytophthora diseases worldwide. APS Press, St. Paul, Minn.

Farr, D. F., and Rossman, A. Y. 2013. Fungal databases, systematic mycology and microbiology laboratory. United States Department of AgricultureAgricultural Research Service, Washington, DC.

Gilbert, G. S. 2002. Evolutionary ecology of plant diseases in natural ecosystems. Annu. Rev. Phytopathol. 40:13-43.

Higginbotham, R. W., Paulitz, T. C., and Kidwell, K. K. 2004. Virulence of Pythium species isolated from wheat fields in Eastern Washington. Plant Dis. 88:1021-1026.

Holmes, K. A., and Benson, D. M. 1994. Evaluation of Phytophthora parasitica var. nicotianae for biocontrol of Phytophthora parasitica on Catharanthus roseus. Plant Dis. 78:193-199.

Jeffers, S. N. 1986. Comparison of two media selective for Phytophthora and Pythium species. Plant Dis. 70:1038-1043.

Jiang, Y. N., Haudenshield, J. S., and Hartman, G. L. 2012. Characterization of Pythium spp. from soil samples in Illinois. Can. J. Plant Pathol. 34: 448-454.

Kang, S. S., Mansfield, M. A. M., Park, B. B., Geiser, D. M. D., Ivors, K. L. K., Coffey, M. D. M., Grünwald, N. J. N., Martin, F. N., Lévesque, C. A. C., and Blair, J. E. J. 2010. The promise and pitfalls of sequencebased identification of plant-pathogenic fungi and oomycetes. Phytopathology 100:732-737.

Kaufmann, M. J., and Gerdemann, J. 1958. Root and stem rot of soybean caused by Phytophthora sojae n. sp. Phytopathology 48:201-208.

Kirkpatrick, M. T., Rupe, J. C., and Rothrock, C. S. 2006. Soybean response to flooded soil conditions and the association with soilborne plant pathogenic genera. Plant Dis. 90:592-596.

Koenning, S. R., and Wrather, J. A. 2010. Suppression of soybean yield potential in the continental United States by plant diseases from 2006 to 2009. Plant Health Prog. doi:10.1094/PHP-2010-1122-1001-RS

Kong, P., Richardson, P. A., and Hong, C. 2005. Direct colony PCR-SSCP for detection of multiple pythiaceous oomycetes in environmental samples. J. Microbiol. Methods 61:25-32.

Kong, P. P., Richardson, P. A. P., Moorman, G. W. G., and Hong, C. C. 2004. Single-strand conformational polymorphism analysis of the ribosomal internal transcribed spacer 1 for rapid species identification within the genus Pythium. FEMS Microbiol. Lett. 240:229-236.

Le Floch, G., Rey, P., Benizri, E., Benhamou, N., and Tirilly, Y. 2003. Impact of auxin-compounds produced by the antagonistic fungus Pythium oligandrum or the minor pathogen Pythium group F on plant growth. Plant Soil 257:459-470. 
Leopold, A. C., and Musgrave, M. E. 1979. Respiratory changes with chilling injury of soybeans. Plant Physiol. 64:702-705.

Lévesque, C. A., and De Cock, A. W. A. M. 2004. Molecular phylogeny and taxonomy of the genus Pythium. Mycol. Res. 108:1363-1383.

Littrell, R. H., and McCarter, S. 1970. Effect of soil temperature on virulence of Pythium aphanidermatum and Pythium myriotylum to rye and tomato. Phytopathology 60:704-707.

Marchand, G., Chen, Y., Berhane, N. A., Wei, L., Lévesque, C. A., and Xue, A. G. 2014. Identification of Pythium spp. from the rhizosphere of soybeans in Ontario, Canada. Can. J. Plant Pathol. 36:246-251.

Martin, F. N., and Loper, J. E. 1999. Soilborne plant diseases caused by Pythium spp.: Ecology, epidemiology, and prospects for biological control. Crit. Rev. Plant Sci. 18:111-181.

Matthiesen, R., Ahmad, A., and Robertson, A. 2016. Temperature affects aggressiveness and fungicide sensitivity of four Pythium spp. that cause soybean and corn damping off in Iowa. Plant Dis. 100:583-591.

Melillo, J. M., Richmond, T., and Yohe, G. W. 2014. Climate change impacts in the United States: the third national climate assessment. US Global Change Research Program, Washington, DC.

Mondal, S. N., and Hyakumachi, M. 2000. Soil factors affecting carbon loss and pathogenecity of oospores of Pythium aphanidermatum. Soil Biol. Biochem. 32:111-118.

Paulitz, T. C., Smiley, R. W., and Cook, R. J. 2002. Insights into the prevalence and management of soilborne cereal pathogens under direct seeding in the Pacific Northwest, U.S.A. Can. J. Plant Pathol. 24:416-428.

Pieczarka, D. J., and Abawi, G. S. 1978. Populations and biology of Pythium species associated with snap bean roots and soils in New York. Phytopathology 68:409-416.

Rizvi, S. S. A., and Yang, X. B. 1996. Fungi associated with soybean seedling disease in Iowa. Plant Dis. 80:57-60.

Robideau, G., De Cock, A. W. A. M., Coffey, M. D., Voglmayr, H., Brouwer, H., Bala, K., Chitty, D. W., Désaulniers, N., Eggertson, Q. A., Gachon,
C. M. M., Hu, C.-H., Küpper, F. C., Rintoul, T. L., Sarhan, E., Verstappen, E. C. P., Zhang, Y., Bonants, P. J. M., Ristaino, J. B., and Lévesque, C. A. 2011. DNA barcoding of oomycetes with cytochrome c oxidase subunit I and internal transcribed spacer. Mol. Ecol. Resour. 11:1002-1011.

Rojas, J. A., Jacobs, J., Napieralski, S., Karaj, B., Bradley, C. A., Chase, T., Esker, P., Smith, D., Giesler, L., Jardine, D., Malvick, D., Markell, S., Nelson, B., Robertson, A., Rupe, J., Sweets, L., Tenuta, A., Wise, K., and Chilvers, M. 2016. Oomycete species associated with soybean seedlings in North America. Published online. doi: 10.5281/zenodo.50107.

Rojas, J. A., Jacobs, J. L., Napieralski, S., Bradley, C. A., Chase, T., Esker, P. D., Giesler, L., Jardine, D., Nelson, B. D., Malvick, D., Markell, S., Robertson, A. E., Rupe, J. C., Sweets, L., Wise, K., and Chilvers, M. I. 2017. Oomycete species associated with soybean seedlings in North America-Part II: Diversity and ecology in relation to environmental and edaphic factors. Phytopathology 107:293-304.

Schlub, R. L., and Lockwood, J. 1981. Etiology and epidemiology of seedling rot of soybean by Pythium ultimum. Phytopathology 71:134-138.

Tsao, P. H., and Guy, S. O. 1977. Inhibition of Mortierella and Pythium in a Phytophthora-isolation medium containing hymexazol. Phytopathology 67: 796-801.

Tyler, B. M. 2007. Phytophthora sojae: root rot pathogen of soybean and model oomycete. Mol. Plant Pathol. 8:1-8.

van der Plaats-Niterink, A. J. 1981. Monograph of the genus Pythium. Stud. Mycol. 1:1-242.

Wrather, A., and Koenning, S. 2009. Effects of diseases on soybean yields in the United States 1996 to 2007. Plant Health Prog. doi:10.1094/PHP-20090401-1001-RS

Zitnick-Anderson, K., Norland, J., del Rio, L., Fortuna, A., and Nelson, B. 2014. Soil properties associated with the presence of Pythium communities in soybean roots. Phytopathology 104:S3.138.

Zitnick-Anderson, K. K., and Nelson, B. D. 2015. Identification and pathogenicity of Pythium on soybean in North Dakota. Plant Dis. 99:31-38. 